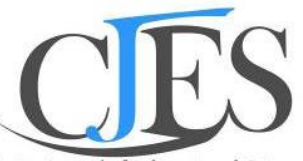

Cypriot Joumal of Educational Sciences

www.cjes.eu

\title{
Twenty-first-century skills acquired by mathematics teachers: school principals' perspectives
}

Mohammad Hamzeh ${ }^{\text {* }}$, Middle East University, Amman, Jordan

Ahmad A.S. Tabieh ${ }^{b}$, Middle East University, Amman, Jordan

Othman Naser Mansour ${ }^{c}$, Middle East University, Amman, Jordan

\section{Suggested Citation:}

Hamzeh, M., Tabieh, A. A. S. \& Mansour, O. N. (2022). Twenty-first-century skills acquired by mathematics teachers: school principals' perspectives. Cypriot Journal of Educational Science. 17(1), 41-55. https://doi.org/10.18844/cjes.v17i1.6680

Received from October 23, 2021; revised from November 21, 2021; accepted from Janurary $02,2022$.

${ }^{\circ} 2022$ Birlesik Dunya Yenilik Arastirma ve Yayincilik Merkezi. All rights reserved.

\begin{abstract}
This study aimed at investigating the acquisition degree of the 21st-century skills of mathematics teachers from the perspective of school principals. The study sample consisted of 75 school principals. They were selected randomly among the public schools. The study instrument consisted of four questionnaires, namely: personal skills, communication skills, technical skills, and teaching skills. Each questionnaire consisted of 30 items. The study results showed that the acquisition degree of the 21 st-skills of mathematics teachers was intermediate for the personal and communication skills while it was high for the technical and teaching skills. The results also showed that there are no statistically significant differences $(\alpha=0.05)$ attributed to the gender variable from the perspectives of the male and female school principals towards the acquisition degree of the 21st-century skills of mathematics teachers. The study recommended utilizing the 21st-century skills of mathematics teachers which will result in improving the teaching process in general.
\end{abstract}

Keywords: Mathematics Teachers, 21st-Century Skills, Personal skills;

\footnotetext{
${ }^{*}$ ADDRESS FOR CORRESPONDENCE: Ahmad A.S., Middle East University, Amman, Jordan

E-mail address: atabieh@meu.edu.jo / Tel.: +0096-279-572-9297
} 
Hamzeh, M., Tabieh, A. A. S. \& Mansour, O. N. (2022). Twenty-first-century skills acquired by mathematics teachers: school principals' perspectives. Cypriot Journal of Educational Science. 17(1), 41-55. https://doi.org/10.18844/cjes.v17i1.6680

\section{Introduction}

\subsection{Theoretical Framework}

Preparing teachers in the $21^{\text {st }}$ century is one of the most important developmental issues on which societies' progress and their ability to face several and fast-evolving challenges are based. The challenges that face global societies are great and it is difficult for the most controlled and receptive future studies to predict their magnitude and impact. Nonetheless, the challenges that face our Arab world are deeper and more complex. Therefore, we need to catch up with the advanced nations and keep pace with global developments. This could only be achieved through building a conscious human being who is committed to their nation's issues, concerns, and dreams; a creative human being who has the capability to innovate and develop, thus fulfilling these obligations.

The developments witnessed by the current century contributed to changes in educational goals. Then, they shifted to focus on life and continuous learning skills, and more comprehensively, the $21^{\text {st }}$ century skills that help students adapt to the changing world and prepare them for competition, creativity, and labor market (Zamel, 2020).

To prepare students properly, teachers should have the skills that are required to fulfill the educational goals and, at the same time, help students acquire the $21^{\text {st }}$-century skills. Undoubtedly, the present age is the age of knowledge-based economy, which means that all individuals have the skills that enable them to live and work in the society of knowledge age (Hefny, 2015). Therefore, preparing teachers is a key need to improve the quality of education.

The count of the skills required to prepare teachers in the $21^{\text {st }}$ century is not easy, especially with the continuous change and renewal which are one of this century's most important features. The teacher is the actual leader of fundamental change in society. Abiding by a clear pattern and a rational and structured way of thinking is imposed on teachers by leading the change. These help them to look ahead and sense the application results of the suggested changes in the educational process, thus making planned changes to ensure the success of the educational process. In the future, the teaching profession will become a combination of the leader, project manager, critic, and counselor tasks (Al-Any, 2018).

The revolution of communication and information technology and its systems had caused wide and important changes. The relative values of knowledge started to emerge in a global society directed to the knowledge-based economy. Consequently, the teachers' chores have increased; they are not only requested to transfer knowledge to learners, but also to develop the learners' capabilities to access different sources of knowledge and optimize their information through seeking effective ways to achieve as much benefit as possible (Al-Qaddah, 2011).

The (Educational-Origami) organization, concerned with education which is based on the integration of knowledge with technology and communication, identifies the most important characteristics of the $21^{\text {st }}$-century teacher as follows (Origami, 2019):

- The Risk Taker: Is the teacher who avoids the risk sources such as the learners' losing the meaning of learning or not being fully educated, the teacher not taking into account the different learning abilities.

- The Collaborator: Is the teacher who takes solidarity-based responsibility with the learners and the whole work foundation to fulfill the goals.

- The Model: Is the teacher who sets an example to their colleagues in work; the devoted teacher who provides quality education. The teacher sets an example of moral values and scientific perseverance to their students

- The Leader: Is the teacher who manages their students according to their different abilities, styles, and cultural elements to the extent that makes students unite with their teacher.

- The Visionary: Is the teacher who has a developmental vision of their professional self and the work foundation as a whole. They are able to work to achieve it as much as possible. 
- The Learner: Is the teacher who develops their professional and academic competencies, either systematically or on their own, according to the possible alternatives. Additionally, they enroll in various training programs.

- The Communicator: Is the teacher who creates a free learning environment to discuss and converse with their students and encourages taking the initiative and speaking spontaneously.

- The Adapter: Is the teacher who adapts the learning environment, learners, educational experience, and assessment tools systematically and consistently to achieve the intended objectives.

Alhothali, (2021) provided a perception of the most important skills that 21st-century teachers should have, they include the following: information and media literacy, critical and systematic thinking, selfdirection, accountability and adaptability, and social responsibility, communication, problem identification and solution formulation, and interpersonal and collaborative skills

Zamel, (2020) pointed out that the $21^{\text {st }}$-century skills include the skills of effective thinking and communication skills, high production, and digital capabilities. The digital capabilities are based on the individual's capabilities to collect, retrieve, and manage information, then assess its quality and importance. Furthermore, they are based on the individual's capabilities to generate accurate information through using the available resources.

However, the partnership for the $21^{\text {st }}$-century skills (2006) sees that they are skills that contain problem-solving, individual creativity, teamwork, innovation, use of technology tools, adaptability, and the ability to solve problems.

Teachers in general, and mathematics teachers in specific, should keep pace with these renewed skills to fit the role of the teacher in the 21st century, who does not only transfer information and knowledge, but also prepare a learner for success in the present century. The traditional teaching methods are no longer useful as the teaching/learning processes are not only restricted to school textbooks and traditional instructional materials, but also the materials of the globalization, speed, and technology era. The skills of the last century teachers do not fit with the 21st-century teacher whose role is not restricted to the transfer of information and knowledge, but also the preparation of a learner for success in the present century (El-Sayed \& Rakza, 2017).

Mathematics, by its nature, is constantly developing. The world countries have been interested in reconsidering the mathematics curricula, the objectives and strategies for teaching it, and the assessment methods of learning it in line with the $21^{\text {st }}$-century requirements. The National Council of Superintendents of Mathematics (NCSM) presented what is called "the essential components of mathematics in the $21^{\text {st }}$ century," which expresses the mathematical competencies and objectives the students need to begin their life as adults in the 21st century (El-Kilany \& Thabet, 2011; Mahmoud, 2015).

\subsection{Related Research}

The researchers reviewed the results of a number of studies related to the teachers' skills in the $21^{\text {st }}$ century. The following is a summary of some of this previous literature:

The study conducted by Zamel, (2020) aimed at defining the roles of the Palestinian teachers in light of the $21^{\text {st }}$-century requirements in Nablus and identifying the ways of activating them. The study sample consisted of 92 male and female school principals and 39 male and female supervisors. a questionnaire was used which is divided into the following four domains: creative and critical thinking and problem-solving, classroom learning management, communication and information and communications technology (ICT), and teaching mastery and students' learning assessment. The results showed that the average degree of the roles of the Palestinian teachers in light of the $21^{\text {st }}$-century 
requirements estimated by school principals and educational supervisors is intermediate. In addition, there were no statistically significant differences according to the gender variable.

ElHoteby, (2018) has also conducted a study that aimed at assessing the teaching performance of science teachers at the preparatory stage in light of the $21^{\text {st }}$-century skills. The study sample consisted of 53 female science teachers in the Asir region in Saudi Arabia. Two study instruments were prepared; a list of the $21^{\text {st }}$-century skills and a questionnaire about the $21^{\text {st }}$-century skills of the science teachers. The questionnaire consisted of 65 items and included four axes, namely: computer skills and their use, participatory skills, communication skills, and thinking skills. The results showed the necessity of working on improving the teaching performance of science teachers in the preparatory stage in line with the $21^{\text {st }}$-century skills.

The study conducted by Al-Momeny, (2018) aimed at revealing the $21^{\text {st }}$-century challenges that face science teachers in public schools in Ajloun. The study sample consisted of 521 male and female teachers. A 30-item questionnaire representing the $21^{\text {st }}$-century challenges that face science teachers was prepared. The results showed that the field of education professionalization ranked first while the field of sustainable education ranked last. Furthermore, the results showed that there were no statistically significant differences attributed to the gender, teaching experience, and educational qualifications variables among the average responses of the teachers on the scale of challenges.

The study of Al-Motlaq, (2016) aimed at identifying a set of competencies required for a successful teacher. In addition, it identified the personal qualities that the teacher should have. The study used the descriptive-analytical approach. The questionnaire was applied to 78 supervisors in Damascus and 1072 male and female students. The results showed a set of qualities the teacher must have, namely: cognitive, respectful of others, intelligent, loyal, interlocutor, and discussant. The results also showed statistically significant differences attributed to the gender variable for females.

The study of Al-Qaddah, (2011) aimed at determining the cognition degree of those who are in charge of learning processes in Jordan (teachers, educational supervisors, and school principals) of the new roles that are supposed to be activated in response to the variables that emerged in the $21^{\text {st }}$-century skills. The study sample consisted of 382 teachers, 274 supervisors, and 351 school principals. Random stratified sampling was used. The researcher developed a questionnaire that has two dimensions. The results showed intermediate levels regarding these categories' cognition of these roles and how they performed them, especially teachers. The results also showed an effect of the qualification variable for the categories that have a higher qualification in cognition and practice. No effect of the experience variable was shown. There are many differences between the educational supervisors and the school principals in cognition and practice as there was a significance for supervisors in cognition and school principals in practice.

The study of Walton \& Linda, (2006) aimed at putting an executive perception to the information technology skills and competencies the teachers at Chicago schools have according to the international standards. The questionnaire was applied to a sample of teachers in Chicago schools. The study reached a number of results, including $60 \%$ of Chicago schools are prepared to implement competencies for the Information Technology (IT) skills according to the international standards. It turns out that there is a significant decline in the fields of both HTML and web design. The results showed that there were no differences attributed to the gender variable.

\subsection{Purpose of the Study}

This study was conducted to keep pace with the development of the mathematics curricula in Jordan after providing newly developed curricula starting from the 2019/2020 academic year. These curricula 
focus on providing the students with the thinking skills and the ingredients for success in the $21^{\text {st }}$ century (Ministry of Education, 2019).

Since teachers are the cornerstone of teaching these curricula, the necessity of verifying the acquisition degree of their $21^{\text {st }}$-century skills emerges since education in this century requires an educated, creative, and contemplative teacher. Otherwise, how they will provide their students with these skills if they are not part of their daily behavior and teaching (Akgün, Işik, Tatar, Işleyen, \& Soylu, 2012).

Additionally, this study was conducted in light of the results of some previous literature, such as the studies of ElHoteby, (2018); Khodeir \& Jasem, (2020); Zamel, (2016) that pointed out the teachers' poor acquisition of the $21^{\text {st }}$-century skills in different countries. Through their work in educational field, researchers found several problems that face teachers which might be due to the teachers' poor acquisition of the 21 st-century skills.

School principals are among the most capable authorities of judging the acquisition degree of these teachers' skills since they work in close proximity to teachers and know accurately all work details (Abdu, 2017).

This study is considered one of the first studies that tackle the acquisition degree of the $21^{\text {st }}$-century skills of mathematics teachers in Jordan, as far as the researchers know.

Specifically, this study attempts to answer the following main question:

To what degree do mathematics teachers acquire the $21^{\text {st }}$-century skills from the perspective of male and female school principals in Amman?

The following sub-questions are derived from this main question:

- To what degree do mathematics teachers acquire personal skills from the perspective of male and female school principals in Amman?

- To what degree do mathematics teachers acquire communication skills from the perspective of male and female school principals in Amman?

- To what degree do mathematics teachers acquire technical skills from the perspective of male and female school principals in Amman?

- To what degree do mathematics teachers acquire teaching skills from the perspective of male and female school principals in Amman?

- Are there any statistically significant differences at the significance level of $(\alpha=0.05)$ between the school principals' perspectives towards the degree of the mathematics teachers' acquisition of the 21st-century skills which are attributed to the gender variable?

\section{Method and Materials}

\subsection{Research Model}

A quantitative (descriptive) approach uses to measure the the teachers' acquisition degree of the following $21^{\text {st }}$-century skills: personal, communication, technical, and teaching skills, the study measured the differences in $21^{\text {st }}$-century skills due to gender using MANOVA.

\subsection{Participants}

The study population consisted of 510 male and female public school principals in Amman (Ministry of Education, 2019).

The study sample consisted of 75 male and female school principals from 75 public schools in Amman. Simple Random sampling was used and The Normality distribution were examined by Kolmogorov- 
Smirnov Test. The test showed that the sampled population is normally distributed with $D(75)=0.083$, $P=200$. Table (1) shows the distribution of the study sample members according to the gender variable.

Table 1. The members of the study samples (male and female school principals) distributed according to the gender variable).

\begin{tabular}{llll}
\hline Variable & & Number & Percentage \\
\hline Gender & Males & 35 & $47 \%$ \\
& Females & 40 & $53 \%$ \\
& Total & 75 & $100 \%$ \\
\hline
\end{tabular}

\subsection{Data Collection Tools}

to identify the degree of the mathematics teachers' acquisition of the $21^{\text {st }}$-century skills from the perspective of male and female school principals in Amman The researchers developed Four questionnaires of five-point Likert scale, each questionnaire consisted from 3 domains, They benefited from the previous literature and the recent studies on this theme, such as the studies of Al-Momeny, (2018); Khodeir \& Jasem, (2020); Zamel, (2020). In addition, an open question was asked to a sample of 20 mathematics teachers in public schools in Amman: "What are the $21^{\text {st }}$-century skills that mathematics teachers should have?", the teachers' responses to this question used also in formulating some of the questionnaire's items. Table (2) represents the domains of each questionnaire and the number of items in each domain.

Table 2. Domains of study instruments and each domain's number of items within each instrument.

\begin{tabular}{llll}
\hline Questionnaire & Questionnaire's Domains & $\begin{array}{l}\text { Numbers of } \\
\text { Items }\end{array}$ & $\begin{array}{l}\text { Total numbers of } \\
\text { Items }\end{array}$ \\
\hline $\begin{array}{l}\text { Personal skills of mathematics } \\
\text { teacher }\end{array}$ & $\begin{array}{l}\text { Leadership skills } \\
\text { Entrepreneurial skills }\end{array}$ & 10 & 30 \\
& Thinking skills & 10 & \\
Communication skills of & Motivation skills & 10 & 30 \\
mathematics teacher & Teamwork skills & 10 & \\
Technical skills of mathematics & Research skills & 10 & 30 \\
teacher & Computer skills & 10 & \\
& E-learning skills & 10 & \\
& Cognitive skills & 10 & 30 \\
Teaching skills of mathematics & Class management skills & 10 & \\
teacher & Skills of using instructional & 10 & \\
\hline
\end{tabular}




\subsection{Data Collection Process}

To check the content validity of the questionnaires, it was presented in its initial form to several specialists in mathematics teaching, measurement and evaluation, educational psychology, to evaluate the questionnaires in terms of accuracy, comprehensiveness of the themes, and the affiliation of each theme's paragraphs. The Instruments modifies according to their observations.

the reliability of the questionnaires has been ensured by applying them to a sample of 20 male and female school principals that is different from the current study sample. The questionnaire was reapplied to the same sample members after two weeks. The correlation coefficient between the two responses was calculated by using the Pearson correlation coefficient. The reliability coefficient was also calculated by using the internal consistency method according to Cronbach's alpha equation. Table (3) shows the internal consistency coefficient according to Cronbach's alpha equation and the reapplication reliability of the domains and instrument as a whole. These values were considered appropriate for this study's purposes.

Table 3. The internal consistency coefficient Cronbach's alpha, and the reapplication reliability of the domains, and total degree.

\begin{tabular}{lll}
\hline Questionnaire & Reapplication reliability & Internal consistency \\
\hline Personal skills of mathematics teacher & 0.92 & \\
Communication skills of mathematics teacher & 0.90 & 0.89 \\
Technical skills of mathematics teacher & 0.93 & 0.82 \\
Teaching skills of mathematics teacher & 0.92 & 0.90 \\
Total degree & 0.91 & 0.90 \\
\hline
\end{tabular}

\subsection{Data Analysis}

- The Normality distribution was tested by Kolmogorov-Smirnovto, to examine the normality of the sample study.

- Frequencies, Percentages, Means and standard deviations were calculated to investigate the question degree of mathematics teachers for the 21st-century skills from school principals' perspectives.

- MANOVA test was employed to find out the significant differences between the school principals' perspectives towards the degree of the mathematics teachers' acquisition of the 21st-century skills which are attributed to the gender variable

\section{Results}

The acquisition degree of the personal skills of mathematics teachers from the perspective of male and female school principals in Amman.

Table (4) shows that the means of the personal skills, in general, is 3.23 with an intermediate degree. The means of the leadership domain reached 3.68 with a high degree. The highest mean was for the following item: "plans educational situations in a way that contributes towards achieving the desired objectives of learning mathematics," and the lowest mean was for the following item: "employs a clear vision and future plan to bring about the desired change in the mathematics learners." It is observed that four out of ten items have a very high degree, four items have a high degree, one item has an 
intermediate degree, and one item has a low degree. This indicates that the mathematics teachers' acquisition of the leadership skills is high.

With regard to the entrepreneurial domain, its means reached 3.22 with an intermediate degree. The highest mean was for the following item: "completes the works related to teaching mathematics ahead of schedule," and the lowest mean was for the following item: "develops the students' self-development skills, such as collaborative work, dialogue, and self-criticism in learning mathematics." It is observed that one out of ten items have a very high degree, two items have a high degree, five items have an intermediate degree, and two items have a low degree. This indicates that the mathematics teachers' acquisition of the entrepreneurial skills is intermediate.

Concerning the means of the thinking skills, it reached 2.80 with an intermediate degree. The highest mean was for the following item: "encourages students to think scientifically when teaching mathematics," and the lowest mean was for the following item: "encourages students to critically read mathematical topics." It is observed that six out of ten items have an intermediate degree and four items have a low degree. This indicates that the mathematics teachers' acquisition of the thinking skills is intermediate.

Table 4. Arithmetic means, standard deviations, ranks, and the acquisition degree of the mathematics teachers' skills.

\begin{tabular}{lllll}
\hline Domain & Personal skills domains & $\begin{array}{l}\text { Arithmetic } \\
\text { mean }\end{array}$ & $\begin{array}{l}\text { Standard } \\
\text { deviation }\end{array}$ & Degree \\
\hline 1 & Leadership skills & 3.68 & 0.74 & High \\
2 & Entrepreneurial skills & 3.22 & 0.85 & Intermediate \\
3 & Thinking skills & 2.80 & 0.65 & Intermediate \\
& Total & 3.23 & 0.75 & Intermediate \\
\hline
\end{tabular}

The acquisition degree of the communication skills of mathematics teachers from the perspective of male and female school principals in Amman.

Table (5) shows that the means of the communication skills, in general, was 3.24 with an intermediate degree. The means of the active communication domain reached 3.70 with a high degree. The highest mean was for the following item: "encourages students to communicate with others," and the lowest mean was for the following item: "contributes to creating understanding-based relationships inside and outside the classroom." It is observed that three out of ten items have a high degree, five items have an intermediate degree, and two items have a low degree. This indicates that the acquisition of the active communication skills of mathematics teachers is high.

The means of the motivation domain reached 2.78 with an intermediate degree. The highest mean was for the following item: "enhances the students' work through engaging as many senses as possible while learning mathematics," and the lowest mean was for the following item: "explains to students the importance of mathematics in our lives and in other sciences." It is observed that one out of ten items have a high degree, four items have an intermediate degree, and five items have a low degree. This indicates that the acquisition of the motivation skills of mathematics teachers is intermediate.

Concerning the means of the teamwork skills, it reached 3.24 with an intermediate degree. The highest mean was for the following item: "provides students with opportunities to cooperate to complete mathematical tasks," and the lowest mean was for the following item: "takes the initiative in participating in volunteer work and helping others." It is observed that five out of ten items have a high 
degree, three items have an intermediate degree, and two items have a low degree. This indicates that the acquisition of the teamwork skills of mathematics teachers is intermediate.

Table 5. Arithmetic means, standard deviations, ranks, and the acquisition degree of the communication skills of mathematics teachers.

\begin{tabular}{lllll}
\hline Domain & Communication skills domains & Arithmetic mean & Standard deviation & Degree \\
\hline 1 & Active communication skills & 3.70 & 0.83 & \\
2 & Teamwork skills & 3.24 & 0.90 & High \\
3 & Motivation skills & 2.78 & 0.99 & Intermediate \\
& Total & 3.24 & 0.91 & Intermediate \\
& & & Intermediate \\
\hline
\end{tabular}

The acquisition degree of the technical skills of mathematics teachers from the perspective of male and female school principals in Amman.

Table (6) shows that the means of the technical skills reached 3.84 with a high degree and the total arithmetic means of the research skills domain reached 3.88 with a high degree. The highest mean was for the following item: "conducts researches on mathematical topics using digital tools," and the lowest mean was for the following item: "takes into account the internet security basics, guiding their students to safe websites related to learning mathematics." It is observed that three out of ten items have a high degree and seven items have a high degree. This indicates that the mathematics teachers' acquisition of the research skills is high.

With regard to the computer skills domain, the means reached 3.78 with a high degree. The highest mean was for the following item: "has skills in dealing with computer programs, such as Word, PowerPoint, and Excel," and the lowest mean was for the following item: "uses e-mail to contact with students, administration, and colleagues." It is observed that two out of ten items have a high degree and eight items have a high degree. This indicates that the mathematics teachers' acquisition of the computer skills is high.

Concerning the means of the e-learning skills domain, it reached 3.86 with a high degree. The highest mean was for the following item: "has skills in designing and producing computerized educational programs in mathematics," and the lowest mean was for the following item: "uses the note-taking tools to share the mathematical content with students." It is observed that one out of ten items have a very high degree, and nine items have a high degree. This indicates that the mathematics teachers' acquisition of the e-learning skills is high.

Table 6. Arithmetic means, standard deviations, ranks, and the acquisition degree of the mathematics teachers' technical skills.

\begin{tabular}{lllll}
\hline Domain & Technical skills domains & Arithmetic mean & Standard deviation & Degree \\
& & & & \\
\hline 1 & Research skills & 3.88 & 0.70 & High \\
2 & E-Learning skills & 3.86 & 0.85 & High \\
3 & Computer skills & 3.78 & 0.80 & High \\
& Total & 3.84 & 0.78 & High \\
\hline
\end{tabular}


The acquisition degree of the teaching skills of mathematics teachers from the perspective of male and female school principals in Amman.

Table (7) shows that the general means of the teaching skills reached 3.80 with a high degree and the arithmetic mean of the cognitive skills reached 3.94 with a high degree. The highest mean was for the following item: "plans mathematics learning situation to stimulate students to think," and the lowest mean was for the following item: "works on creating an information base which was deep, comprehensive, and up-to-date in the field of mathematics." It is observed that two out of ten items have a very high degree and eight items have a high degree. This indicates that the mathematics teachers' acquisition of the cognitive skills is high.

With regard to the class management domain, its means reached 3.75 with a high degree. The highest mean was for the following item: "works on providing a physical environment that encourages learning in mathematics sessions inside and outside the classroom," and the lowest mean was for the following item: "uses constructive feedback and reinforcement techniques to guide students." It is observed that all ten items have a high degree and this indicates that the mathematics teachers' acquisition of the class management skills is high.

The means of using instructional materials reached 3.70 with a high degree. The highest mean was for the following item: "uses audio and visual materials in teaching mathematics," and the lowest mean was for the following item: "evaluates the effectiveness degree of the material after using it to develop and modify it in a way that increases its contribution to the achievement of the desired objectives." It is observed that two out of ten items have a very high degree, six items have a high degree, and two items have an intermediate degree. This indicates that the mathematics teachers' acquisition of the skills of using instructional materials is high.

Table 7. Arithmetic means, standard deviations, ranks, and the acquisition degree of the mathematics teachers' teaching skills.

\begin{tabular}{lllll}
\hline Domain & Teaching skills domains & Arithmetic mean & Standard deviation & Degree \\
\hline 1 & Cognitive skills & 3.94 & 1.06 & \\
2 & Class Management skills & 3.75 & 1.34 & High \\
3 & Skills of using instructional materials & 3.70 & 1.60 & High \\
& Total & 3.80 & 1.33 & High \\
& & & High \\
\hline
\end{tabular}

Differences between the perspectives of male and female school principals on the mathematics teachers' acquisition degree of the $21^{\text {st }}$-century skills.

The results in Table (8) show that there are apparent differences between the arithmetic means of the teachers' responses to the four questionnaires according to their gender. To find these differences between the arithmetic means according to gender, the multi-way Anova (MANOVA) was used. Table (9) shows these results.

Table 8. Arithmetic means and standard deviations of the responses of male and female school principals on the teachers' acquisition of skills according to gender.

Domain Gender Number Arithmetic mean Standard deviation


Hamzeh, M., Tabieh, A. A. S. \& Mansour, O. N. (2022). Twenty-first-century skills acquired by mathematics teachers: school principals' perspectives. Cypriot Journal of Educational Science. 17(1), 41-55. https://doi.org/10.18844/cjes.v17i1.6680

\begin{tabular}{lllll}
\hline Personal skills of mathematics teachers & Males & 35 & 3.19 & 0.91 \\
& Females & 40 & 3.28 & 0.59 \\
Communication skills of mathematics teachers & Males & 35 & 3.28 & 0.90 \\
& Females & 40 & 3.20 & 0.93 \\
Technical skills of mathematics teachers & Males & 35 & 3.91 & 0.65 \\
& Females & 40 & 3.76 & 0.86 \\
Teaching skills of mathematics teachers & Males & 35 & 3.88 & 1.66 \\
& Females & 40 & 3.71 & 0.99 \\
Total & Males & 35 & 3.61 & 1.03 \\
& Females & 40 & 3.56 & 0.93 \\
\hline
\end{tabular}

Table 9. Multi-Way MANOVA to compare the responses of the male and female school principals according to the gender variable.

\begin{tabular}{|c|c|c|c|c|c|c|}
\hline Domain & MANOVA & $\begin{array}{l}\text { Total } \\
\text { squares }\end{array}$ & $\begin{array}{l}\text { Free } \\
\text { degrees }\end{array}$ & $\begin{array}{l}\text { Squares } \\
\text { average }\end{array}$ & $\begin{array}{l}\text { (P) } \\
\text { Value }\end{array}$ & $\begin{array}{l}\text { Significance } \\
\text { level }\end{array}$ \\
\hline \multirow{3}{*}{$\begin{array}{l}\text { Personal skills of mathematics } \\
\text { teachers }\end{array}$} & Gender & 1.03 & 1 & 1.03 & 3.68 & 0.16 \\
\hline & Error & 95.98 & 73 & 0.50 & & \\
\hline & Total & 96.84 & 74 & & & \\
\hline \multirow{3}{*}{$\begin{array}{l}\text { Communication skills of } \\
\text { mathematics teachers }\end{array}$} & Gender & 1.30 & 1 & 1.30 & 5.21 & 0.07 \\
\hline & Error & 116.30 & 73 & 0.50 & & \\
\hline & Total & 117.61 & 74 & & & \\
\hline \multirow{3}{*}{$\begin{array}{l}\text { Technical skills of } \\
\text { mathematics teachers }\end{array}$} & Gender & 0.33 & 1 & 0.33 & 5.29 & 4.51 \\
\hline & Error & 116.30 & 73 & 0.46 & & \\
\hline & Total & 116.63 & 74 & & & \\
\hline \multirow{3}{*}{$\begin{array}{l}\text { Teaching skills of mathematics } \\
\text { teachers }\end{array}$} & Gender & 0.29 & 1 & 0.29 & 6.85 & 0.11 \\
\hline & Error & 102.51 & 73 & 0.43 & & \\
\hline & Total & 102.80 & 74 & & & \\
\hline \multirow[t]{3}{*}{ Total } & Gender & 2.66 & 1 & 2.65 & 0.17 & 0.078 \\
\hline & Error & 714.71 & 73 & 3.09 & & \\
\hline & Total & 717.37 & 74 & & & \\
\hline
\end{tabular}


The results in Table (9) shows that there were no statistically significant differences between the perspectives of the male and female school principals on the acquisition degree of the mathematics teachers' $21^{\text {st }}$-century skills attributed to the gender variable, where the " $\mathrm{P}$ " value was not statistically significant at the significance level of $(\alpha=05.0)$ in all domains and the total degree.

\section{Discussion}

\subsection{The mathematics teachers' personal skills are average in general}

The researchers attribute the high degree of the mathematics teachers' acquisition of the personal leadership skills to the fact that mathematics, by its nature, depends on order, sequence, planning, and being away from randomness. This is reflected in mathematics teachers where you find that most of them are organized and work according to clear order and steps, and this was confirmed by the study of (Akgün et al., 2012).

The intermediate degree of the mathematics teachers' acquisition of the entrepreneurial skills is due to the great work stress on mathematics teachers from planning, implementation, and evaluation, to other tasks such as shifts, records, etc. This hinders them from pursuing excellence and searching for new creative ideas.

Concerning the intermediate degree of the mathematics teachers' thinking skills, it is due to the information amount of school curricula, the dominance of the traditional methods among most mathematics teachers, as pointed out by the study of Jacobbe \& Millman, (2009), and the mathematics teachers' keenness on finishing the curricula on time. This prompts them to use the educational methods that focus on providing students with information and neglecting other aspects, such as training students to think critically and solve problems.

\subsection{The mathematics teachers' communication skills are high in general}

The researchers attribute the high degree of the mathematics teachers' active communication skills to the training provided by the Ministry of Education for mathematics teachers where they are trained in many training programs that focus on the communication skills and respecting the opinions of others.

Concerning the intermediate degree of the mathematics teachers' motivation skills, it is attributed to the fact that a lot of students consider. Mathematics as a dry and difficult subject and do not like it. This increases the difficulty of the teachers' tasks in motivating students and enticing them to like mathematics.

The intermediate degree of the mathematics teachers' teamwork skills is due to the big momentum in Mathematics and its topics, the semester's shortage of time, and the difficulty of making group or voluntary activities.

\subsection{The mathematics teachers' technical skills are high in general}

The researchers attribute the high degree of the mathematics teachers' research skills to the fact that these skills have become one of the general culture basics that most teachers have in our time as they 
have access to the internet, have the skills of searching on it and using it in following up on the mathematics-related updates, and be aware of all the updates in their field of specialization.

The researchers also attribute the high degree of the mathematics teachers' computer skills to the fact that the vast majority of mathematics teachers hold the International Certificate of Digital Literacy (ICDL) and there is a salary increase for teachers who obtain this certificate (Bani Atta, 2010). In addition, the mathematics teachers' scientific background and their studies at the university make them closely related to computers, their applications, and how to use them.

With regard to the e-learning skills, the researchers believe that the high degree of the mathematics teachers' acquisition of these skills is due to the coronavirus pandemic that the world, including Jordan, is going through and the move to distance learning during this pandemic. These reasons give mathematics teachers good experience in dealing with electronic education and utilizing it in teaching and evaluation.

\subsection{The mathematics teachers' teaching skills are high in general}

The researchers attribute the mathematics teachers' cognitive skills to the fact that most mathematics teachers hold a bachelor's degree in mathematics. This makes mathematics teachers master the mathematical knowledge and give them the ability to mathematically relate, represent, and analyze. In addition, there is training provided by the Ministry of Education to them.

The high degree of the mathematics teachers' class management skills is due to the fact that mathematics is one of the most important basic subjects for students. This is represented in the students' keenness on listening attentively to the teacher and focusing on all the presented ideas. This reflects the calm atmosphere inside the classroom and makes it easier for mathematics teachers to manage the classroom. Furthermore, distance learning during the coronavirus pandemic reduced the behavioral problems and the class management problems that teachers face in general.

The researchers attribute the high degree of using the instructional materials to the fact that using computers and educational platforms during the period of distance learning requires teachers to use audio and visual instructional materials and modern technology tools in teaching mathematics.

\subsection{No Differences on the acquisition degree of the 21st-century skills of mathematics teachers due to gender}

The researchers attribute this to the fact that male and female mathematics teachers receive the same training opportunities, regardless of their gender, and they teach the same mathematics curricula.

The gender-variable-related results of this study are consistent with the results of the studies of AlMomeny, (2018); Walton \& Linda, (2006); Zamel, (2020). However, the results of other studies showed differences attributed to the gender variable for males in the study of Melhem, (2017) and for females in the study of Al-Motlaq, (2016).

\section{Conclusion}

- Public school principals in Jordan see that the mathematics teachers' personal skills are average in general with a high degree in the leadership skills and an intermediate degree in both the entrepreneurial and thinking skills. 
- Public school principals in Jordan see that the mathematics teachers' communication skills are high in general with a high degree in the active communication skills and an intermediate degree in both the teamwork and motivation skills

- Public school principals in Jordan see that the mathematics teachers' technical skills are high in general with a high degree in the research, e-learning, and computer skills.

- Public school principals in Jordan see that the mathematics teachers' teaching skills are high in general with a high degree in the cognitive, class management, and using instructional materials skills.

- Male and female public-school principals in Jordan agreed on the acquisition degree of the 21stcentury skills of mathematics teachers in all personal, communication, technical, and teaching domains.

\section{Recommendations}

In light of the current study explanations and results, the researcher recommends the following:

- Benefiting from the 21st-century skills and their classification in this study, encouraging teachers to identify them, and pursuing their acquisition.

- Training mathematics teachers to acquire the 21st-century skills and this will lead to the improvement of the teaching process in general.

- The continuous diagnosis of the mathematics teachers' acquisition degree of the 21st-century skills.

- Conducting similar studies on mathematics teachers and teachers of other subjects in various environments to identify their acquisition of the 21st-century skills from the perspective of the teachers themselves or the educational supervisors and the students.

\section{References}

Abdu, A. (2017). The degree of the Alshobak Brigade teachers' acquisition of the skills of using instructional materials. Al-Hussein Bin Talal University Research Journal, 3(1), 1-23.

Akgün, L., Işik, C., Tatar, E., Işleyen, T., \& Soylu, Y. (2012). Transfer of Mathematical Knowledge: Series. Australian Journal of Teacher Education, 37(3). https://doi.org/10.14221/ajte.2012v37n3.2

Al-Any, Z. (2018). Educational Values and Critical Thinking Skills in the 21st century to the students of the primary stage in Iraq. 26(2), 343-374.

Alhothali, H. M. (2021). Inclusion of 21st Century Skills in Teacher Preparation Programs in the Light of Global Expertise. International Journal of Education and Practice, 9(1), 105-127.

Al-Momeny, J. (2018). The 21st-century challenges that face science teachers in public schools in Ajloun. The Journal of al-Quds Open University for Research \& Studies, 1(43), 186-197.

Al-Motlaq, F. (2016). The competencies and qualities of the successful teacher from the perspective of councilors and students: A field study in the secondary stage in Damascus. Journal of Arab Universities Union of Education and Psychology, 14(2), 47-82. 
Al-Qaddah, M. (2011). The awareness degree of those who are in charge of the learning process in Jordan of their new roles in the 21st century and practicing them. The Jordanian Journal of Educational Sciences, 7(1), 77-95.

Bani Atta, Z. (2010). Creating a scale for the teachers' attitudes towards the International Certificate of Digital Literacy. Journal of Educational and Psychological Sciences, 10(4), 117-144.

ElHoteby, D. A. E. E. (2018). Evaluation of teaching performance science teachers in the middle stage on the light of 21st-century skills. International Journal of research in Educational Sciences. (IJRES), 1(4), 261-292.

El-Kilany, M., \& Thabet, N. (2011). The effect of using instructional materials in mathematics sessions from the perspective of the students themselves. Directorate of Education, Nablus, Palestine.

El-Sayed, S., \& Rakza, S. (2017). Horizons for preparing a mathematics teacher in Prince Sattam Bin Abdulaziz University in the 21st century. Al-Jami' Journal of Psychological Studies and Educational Sciences, (7), 65-91.

Hefny, M. (2015). The skills of the 21st-century teacher. Presented at the The 24th Scientific Conference of the Egyptian Association for Curriculum and Teaching Methods - The Third International: Teacher preparation programs in universities for excellence, Assiut University, Egypt.

Jacobbe, T., \& Millman, R. S. (2009). Mathematical Habits of the Mind for Preservice Teachers. School Science and Mathematics, 109(5), 298-302. https://doi.org/10.1111/j.19498594.2009.tb18094.x

Khodeir, N., \& Jasem, J. (2020). The 21st-century skills for the students of the Mathematics Department in the Faculty of Education. Journal of Arts, Literature, Humanities, and Sociology, (58), 418434.

Mahmoud, M. (2015). Sources for Developing Mathematics Education. Dar Al-Manhal, Jordan.

Melhem, A. (2017). The acquisition degree of the 21st-century skills in the Technology course for the upper primary stages and the students' acquisition degree of these skills (An unpublished master's thesis). An-Najah National University, Nablus.

Ministry of Education. (2019). The Strategic Plan of the Ministry of Education 2018-2022. Planning Management.

Origami. (2019). 21st Century Teachers | Educational Origami. Retrieved October 12, 2019, from https://edorigami.edublogs.org/2008/05/12/21st-century-teachers/

Walton, T., \& Linda, B. (2006). Information Technology Teachers' Perception of Implementing the National Education Technology Standards. Colorado State University.

Zamel, M. (2016). Suggested Visions for the 21stcentury school in Palestine. Journal of the Islamic University of Psychological and Educational Studies, 24(4), 48-73.

Zamel, M. (2020). Roles practiced by Palestinian teachers in light of the 21 st-century requirements and ways to activate them in Nablus. Hebron University Research Journal, 11(2), 124-156. 